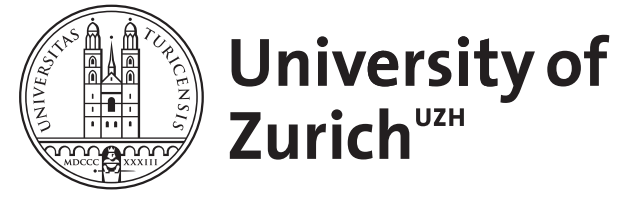

\title{
B-cell responses in allergen immunotherapy
}

\author{
Satitsuksanoa, Pattraporn ; van de Veen, Willem ; Akdis, Mübeccel
}

\begin{abstract}
URPOSE OF REVIEW: The establishment of long-term clinical tolerance in AIT requires the involvement of basophils, mast cells, allergen-specific regulatory $\mathrm{T}$ and $\mathrm{B}$ cells, downregulation of effector type 2 responses, and increase in production of specific IgG, particularly immunglobulin G4 (IgG4) antibodies. This review aims to provide an overview of the role of B cells in AIT, their mechanism of action, and their potential for improving AIT. RECENT FINDINGS: In-depth research of B cells has paved the way for improved diagnosis and research on allergic diseases. B cells play a central role in allergy and allergen tolerance through the production of immunglobulin E (IgE)-blocking antibodies. However, an increasing body of evidence has emerged supporting a role for B cells in regulating immune responses that extends beyond the production of antibodies. Regulatory B cells play an important role in immunosuppression, mediated by secretion of anti-inflammatory cytokines. SUMMARY: Successful AIT establishes the reinstatement of immune tolerance toward allergens, reduces allergic symptoms, and improves clinical treatments in patients. B cells play a central role in this process through antibodyindependent immune regulatory processes in addition to the production of IgE-blocking antibodies.
\end{abstract}

DOI: https://doi.org/10.1097/aci.0000000000000580

Posted at the Zurich Open Repository and Archive, University of Zurich

ZORA URL: https://doi.org/10.5167/uzh-179536

Journal Article

Published Version

Originally published at:

Satitsuksanoa, Pattraporn; van de Veen, Willem; Akdis, Mübeccel (2019). B-cell responses in allergen immunotherapy. Current Opinion in Allergy and Clinical Immunology, 19(6):632-639.

DOI: https://doi.org/10.1097/aci.0000000000000580 


\title{
B-cell responses in allergen immunotherapy
}

\author{
Pattraporn Satitsuksanoa ${ }^{\mathrm{a}, \mathrm{b}}$, Willem van de Veen ${ }^{\mathrm{a}, \mathrm{b}}$, and Mübeccel Akdis ${ }^{\mathrm{a}, \mathrm{b}}$
}

\begin{abstract}
Purpose of review
The establishment of long-term clinical tolerance in AIT requires the involvement of basophils, mast cells, allergen-specific regulatory $T$ and $B$ cells, downregulation of effector type 2 responses, and increase in production of specific lgG, particularly immunglobulin $G 4$ (lgG4) antibodies. This review aims to provide an overview of the role of B cells in AIT, their mechanism of action, and their potential for improving AIT.
\end{abstract}

\section{Recent findings}

In-depth research of B cells has paved the way for improved diagnosis and research on allergic diseases. $B$ cells play a central role in allergy and allergen tolerance through the production of immunglobulin $E$ (lgE)-blocking antibodies. However, an increasing body of evidence has emerged supporting a role for B cells in regulating immune responses that extends beyond the production of antibodies. Regulatory $B$ cells play an important role in immunosuppression, mediated by secretion of anti-inflammatory cytokines.

\begin{abstract}
Summary
Successful AIT establishes the reinstatement of immune tolerance toward allergens, reduces allergic symptoms, and improves clinical treatments in patients. B cells play a central role in this process through antibody-independent immune regulatory processes in addition to the production of $\mathrm{lgE}$-blocking antibodies.
\end{abstract}

\section{Keywords}

allergen-specific immunotherapy, anti-inflammatory cytokines, $\lg E$, $\lg G 4$, immune tolerance, regulatory $B$ cells

\section{INTRODUCTION}

Allergic diseases remain a major global health problem causing significant morbidity and mortality and accounting for a considerable portion of healthcare expenditures [1]. Allergic diseases develop from many heterogeneous diseases with different clinical manifestations. These diseases generally result from an uncontrolled inflammatory response to allergens and can lead to a number of disorders, including food allergy, asthma, allergic rhinoconjunctivitis, atopic dermatitis, and anaphylaxis [2]. Food allergy is affecting up to $8 \%$ of children and $5 \%$ of adults in westernized countries and, development of therapies for this potentially life-threatening condition has become a public health priority [3]. Allergic rhinoconjunctivitis is an allergic disorder of the nose and eyes affecting about a fifth of the general population [4]. The prevalence of atopic dermatitis in longitudinal birth cohort studies is similar in childhood and adolescence/early adulthood [5]. Anaphylaxis occurs with an incidence of 1.5-7.9 per 100000 people/year [6].

There are different endotypes in allergic disorders, which are defined by the compilation of disease mechanisms explaining disease expression in groups of patients. The most common endotypes for allergic diseases are type 2 and nontype 2 ; however, recent data have emerged in support of inflammasome subtype, barrier subtype, type 17 subtype, and mixed types such as type 2/type 1 and type 2/type 17 as well as allergen-specific immunotherapy (AIT)responsive endotype [1].

For example, the endotypes in food allergy consists of immunglobulin E (IgE)-mediated immediate hypersensitivity reactions, non-IgE-mediated reactions, and disorders with mixed IgE-mediated and cell-mediated immune reactions [7"']. IgE-mediated allergies are typically immediate onset with reactions ranging from mild to severe to life-threatening anaphylactic reactions involving single or multiple organs. Non-IgE and mixed endotypes could be shown in food protein-induced enterocolitis syndrome (FPIES) and eosinophilic esophagitis (EoE). FPIES, diagnosed in infants and toddlers (with

\footnotetext{
${ }^{a}$ Swiss Institute of Allergy and Asthma Research (SIAF), University of Zurich and ${ }^{\mathrm{b}}$ Christine Kühne-Center for Allergy Research and Education (CK-CARE), Davos, Switzerland

Correspondence to Mübeccel Akdis, MD, PhD, Swiss Institute of Allergy and Asthma Research (SIAF) Herman-Burchard-Strasse 9, CH- 7265 Davos, Switzerland. Tel: +41 81 4100848; fax: +41 81 4100840; e-mail: akdism@siaf.uzh.ch
}

Curr Opin Allergy Clin Immunol 2019, 19:632-639 DOI:10.1097/ACI.0000000000000580 


\section{KEY POINTS}

- AIT induces clinical immune tolerance by reducing symptoms of allergic patients and has been used as a possible curative treatment for allergies for more than a century.

- Breg cells play an important role in induction and maintenance of immune tolerance during AIT through IL10-mediated suppression of effector T cells, inhibition of dendritic cell maturation, induction of Treg cells and production of antiinflammatory lgG4 antibodies.

- Recently introduced knowledge on the role of B cells in AIT are beneficial for vaccine development and may lead to improved AIT strategies for the treatment of allergic patients.

spontaneous resolution within $1-5$ years), includes reactions with vomiting and diarrhea primarily because of food allergy to cow's milk or soy's milk [8]. Patients with EoE have increased levels of thymic stromal lymphopoietin, whereas patients with EoE-like disease can be distinguished from EoE by eotaxin-3, Mucin 4, and cadherin-like protein 26 expression levels [9]. Recently, it was shown that desmoglein-1, an intracellular adhesion molecule, is downregulated by IL-13 leading to impaired barrier function. Tracking of desmoglein-1 in individuals with EoE can aid in diagnosis and management, leading to improved precision medicine [10]. Recent studies have shown that children with EoE have high or very high titers of immunglobulin G4 (IgG4) and low but detectable IgE [11].

One of the most successful treatments that are available for allergic patients is AIT [12-14]. AIT is an immune tolerance-inducing treatment that reduces symptoms of allergic rhinitis and asthma as well as venom allergy and food allergy [15"',16-18]. It involves the administration of increasing doses of the causative allergen and induces the establishment of long-term clinical tolerance against allergens [19-21]. Routes of AIT consist of subcutaneous immunotherapy (SCIT) and sublingual immunotherapy (SLIT). SCIT is used as a reference therapy and has transformed allergic treatments; it improves symptoms (asthma and rhinitis) as well as the quality of life of patients $[22,23]$. SLIT is now a valid noninvasive alternative to SCIT, as a well-tolerated and efficacious treatment for respiratory allergies [24-27].

The molecular and cellular mechanisms of allergen tolerance in humans have been intensively studied during the past decades, leading to the identification of crucial processes in the induction and maintenance of allergen tolerance. These include induction of allergen-specific regulatory subsets of
$\mathrm{T}$ and $\mathrm{B}$ cells, secretion of immune suppressive secreted factors such as IL-10 and transforming growth factor- $\beta$ (TGF- $\beta$ ), production of allergen-specific IgG4 blocking antibodies, and a decrease in allergic inflammatory responses by mast cells, basophils, and eosinophils in inflamed tissues $[28,29]$. It has been known that regulatory $\mathrm{T}$ cells play a central role in the induction and maintenance of allergen tolerance [30]; however, data supporting a role for B cells in these processes have been increasing in recent years. In this review, we discuss the role of B cells in allergen-specific immunotherapy (AIT).

\section{MECHANISM OF ALLERGEN-SPECIFIC IMIMUNOTHERAPY}

Common allergens originate from naturally occurring proteins of plant and animal-origin [31]. The allergens are initially broken down by hydrolytic enzymes in the gastrointestinal tract during the digestive process. It is hypothesized that allergens can be modified into different forms and different structures, which can be processed by antigen-presenting cells, presented on the major histocompatibility complex class II molecules and subsequently recognized by antigen-specific $T$ cells. The naïve antigen-specific $\mathrm{T}$ helper cells differentiate into effector T-helper 2 (Th2) cells in the presence of IL-4. A set of interleukins such as IL-4, IL-5, IL-10, and IL-13 are produced by Th2 cells and induce B cells to differentiate into IgE-producing plasma cells. Antigen-specific IgE antibodies directly bind to high-affinity receptor FceRI on mast cells and basophils. Upon reexposure to the allergen, these specific IgE antibodies induce degranulation of mast cells and release of mediators including cytokines, histamine, and proteases which result in allergic symptoms [ $\left.7^{-"}\right]$.

Immunological tolerance is an active process of immune responses to specific antigens [32]. The development of allergen tolerance is often associated with an increase in allergen-specific regulatory $\mathrm{T}$ (Treg), regulatory B (Breg) cells, allergen-specific IgG4 antibody production, and decreased activation of effector cells, such as basophils, mast cells, and eosinophils. Treg and Breg cells are considered as the major instrumental cells that have immunosuppressive effects $[33,34]$. The effects of IL-10 on monocytes and macrophages include inhibition of the production and release of mediators and antigenpresentation and the enhancement of phagocytosis [35]. IL-10 directly acts on CD4 ${ }^{+} \mathrm{T}$ cells and downregulates IL- 2 and interferon gamma- $\gamma$ production by Th1 cells and of IL- 4 and IL-5 production by Th2 cells [36]. The induction of type 2 immune response that consists of Th2 cells and type 2 innate 
lymphoid cells (ILC2) together with the production of allergen-specific IgE antibodies and increased eosinophil numbers in the affected tissues and peripheral blood is a cause of allergic diseases [37-39]. The overview of the mechanism of AIT is explained in Fig. 1. These allergic symptoms have often reduced the quality of human life on a daily basis $[40,41]$.

For several decades, the underlying mechanism of AIT has been intensively studied to understand the complexity of allergen-specific immune responses at both molecular and cellular levels [42,43]. In brief, molecular and cellular events that occur during AIT can be separated into 4 stages. Within a few hours of allergen exposure, there is a decrease in mast cell and basophil activity and degranulation. This stage is called early desensitization. Then, within a few days, allergen-specific Treg and Breg cells are generated, which leads to the suppression of allergen-specific effector T-cell subsets are generated. After a few weeks to months, the allergen-specific antibodies IgE-toIgG4 ratio decreases substantially. Finally, decreases in tissue mast cells, eosinophils, and release of their mediators are observed after several months after AIT [28]. Interestingly, allergen-specific Treg and Breg cells and their microenvironmental cytokines are important for determining success or failure in immunotherapy AIT [30,44].

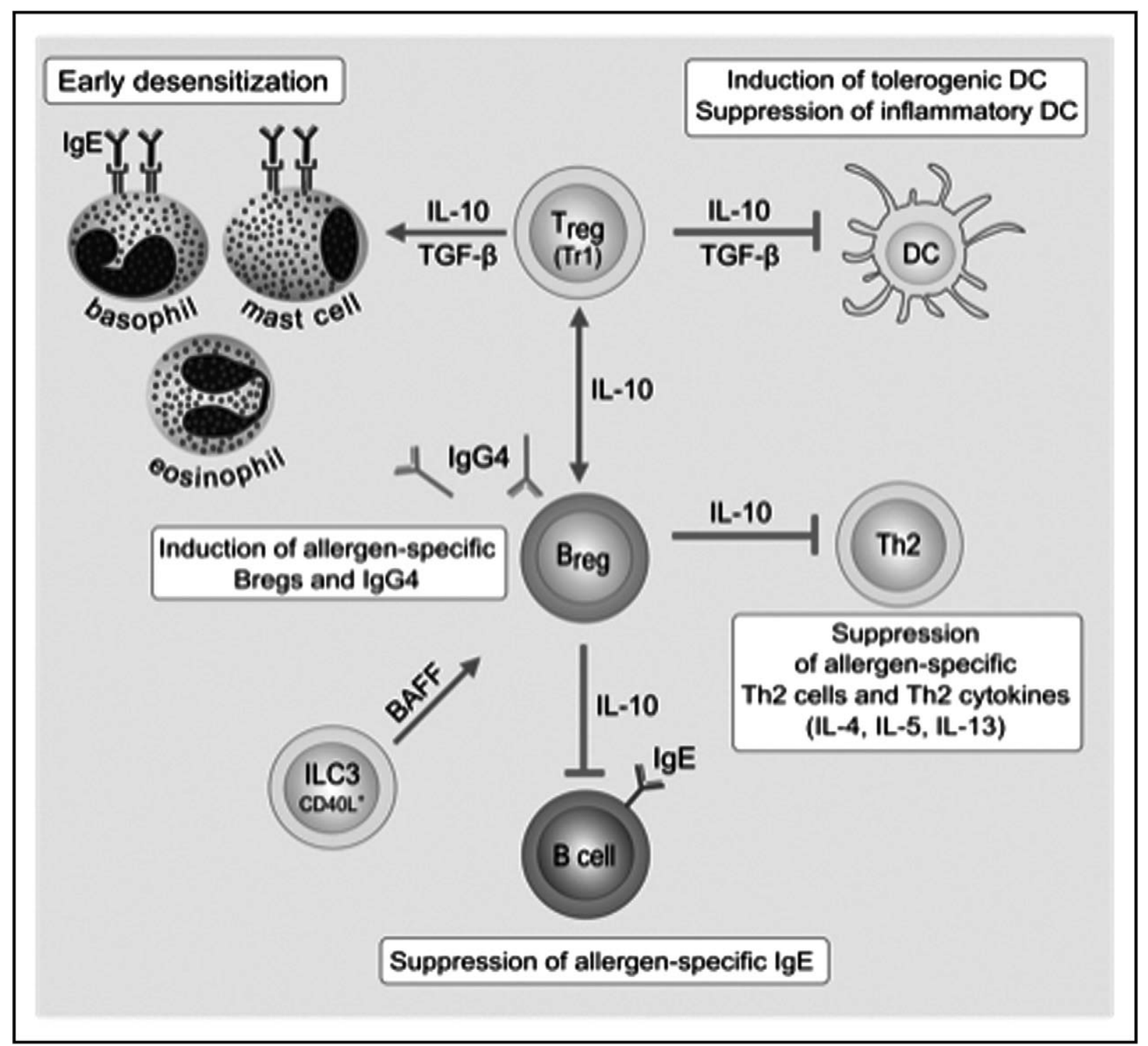

FIGURE 1. The development of allergen tolerance in AIT. AIT, Allergen-specific immunotherapy; Breg, regulatory B cells; ILC2, group 2 innate lymphoid cells; ILC3, group 3 innate lymphoid cells; TGF- $\beta$, transforming growth factor- $\beta$; Th2, T-helper 2 cells; $T r 1$, allergen-specific regulatory $T$ cells; Treg, regulatory $T$ cells. 
THE INDUCTION AND DEVELOPMENT OF REGULATORY B CELLS

Komlósi et al. [45"] demonstrated that activated CD40 ligand (CD40L)-expressing type 3 innate lymphoid cells (ILC3s) play an important role in Breg cell induction in human tonsils. These human circulating ILC3s were able to differentiate into the activated form of ILC3s (CD40L ${ }^{+}$ILC3s) in the presence of IL-15. Tonsillar epithelial cells and Myeloid Dendritic cells contribute to the supporting microenvironment of $\mathrm{CD}_{40 \mathrm{~L}^{+}} \mathrm{ILC}_{\mathrm{s}}$ in the tissue through their IL-15 production. Naive B cells upregulated IL-15 expression on interaction with ILC3s, and $\mathrm{CD}_{40 \mathrm{~L}}^{+}$ILC3-induced IL-15 production was mediated by B cell activating factor (BAFF) in a BAFF receptor-dependent manner. Then, $\mathrm{CD} 40 \mathrm{~L}^{+}$ILC3s induce the development of IL-10-secreting, programmed death-ligand 1-expressing functional Breg cells.

In addition, IL-10 cytokine that plays essential roles as an effector or regulatory molecules in both innate and adaptive immune responses is secreted not only in B cells [34]. The generation of IL-10 and TGF- $\beta$-producing allergen-specific regulatory $\mathrm{T}$ cells (Tr1) have a potential to inhibit Th2-type responses and suppress other effector $\mathrm{T}$ cells through multiple mechanisms engaging cytotoxic T-lymphocyteassociated protein 4, programmed death-1 and histamine receptor 2 [46]. During AIT, IL-10 is primarily produced by allergen-specific Treg cells [47"], subsequently by allergen-specific Breg cells (Br1 cells), and monocytes. In bee venom-allergic patients, these IL-10-secreting Tr1 cells are substantially increased very early after the start of bee venom AIT and persist in high-dose exposure to allergen models, such as nonallergic beekeepers and cat owners [48-51]. Tr1 cells are also generated in response to other immunotherapies such as sublingual immunotherapy, immunotherapy against other allergens such as grass pollen and house dust mites, and peptide immunotherapies in allergy and autoimmune diseases [52,53,54"']. The immunosuppressive properties of Treg cells are also regulated by IL-10 producing Tr 1 cells and $\mathrm{CD} 4{ }^{+} \mathrm{CD} 25^{+}$Treg cells [55]. Moreover, IL-10 together with TGF- $\beta$ revealed the inhibitory functions through the other subset of Treg cells, inducible $\mathrm{T}$ cell co-stimulator $(\mathrm{ICOS})^{+}$forkhead box P3 ${ }^{+}$Treg cells [56]. IL-10 suppresses $\mathrm{T}$ cells via CD28 and ICOS-dependent $\mathrm{T}$-cell costimulation by precisely blocking proliferation and cytokines production [57]. In a mice model, the transfer of ovalbumin peptide-specific $\mathrm{CD}^{+}{ }^{+} \mathrm{CD} 25^{+} \mathrm{T}$ cells to OVA-sensitized mice was determined to be IL-10 dependent. Kearley et al. [58] demonstrated that the transfer of $\mathrm{CD}^{+}$ $\mathrm{CD} 25^{+} \mathrm{T}$ cells leads to an increased expression of
IL-10 in the lungs and to a decrease in airway hyperreactivity and the recruitment of eosinophils and Th2 cytokines to airways after an allergen challenge. These effects were reversed by administration of an anti-IL-10R antibody [58]. SLIT with systemic administration of IL-2 associated with an anti-IL-2 monoclonal antibody (IL-2/anti-IL-2Ab complex or IL-2C) rendered Treg-mediated tolerance and reversed the IgE-mediated food allergy in mice [59].

Three different IL-10 $0^{+}$Breg subsets have been identified in humans. $\mathrm{CD} 19^{+} \mathrm{CD} 5^{+} \mathrm{CD} 1 \mathrm{~d}^{+}$ and $\mathrm{CD} 19^{+} \mathrm{CD} 24^{+} \mathrm{CD} 38^{+}$Bregs were shown to suppress Th1 cells [60,61], whereas $\mathrm{CD} 19^{+} \mathrm{CD} 25^{+} \mathrm{CD} 71^{+} \mathrm{CD} 73^{-}$-inducible Breg cells may play a role in allergen-specific immune tolerance [62"']. These inducible Breg cells (or Br1 cells) are immunosuppressive B cells that regulate excessive inflammation via the release of IL-10, which induce differentiation of regulatory $\mathrm{T}$ cells and inhibit proinflammatory responses and augment IgG4 production $\left[7^{" *}, 63^{"-}, 64^{-"}, 65^{\prime \prime}, 66\right]$.

Our group investigated the role of B cells in AIT, by comparing B-cell responses in allergic patients before and during AIT and naturally exposed healthy beekeepers before and during the beekeeping season. Br1 cells are characterized by high expression of CD25 and CD71 and low expression of CD73 on the cell surface. We demonstrated that phospholipase A2 (PLA)-specific B cells showed similar responses in allergic patients and beekeepers after venom exposure. Both groups showed increased frequencies of plasmablasts, PLA-specific memory B cells, and IL-10-secreting $\mathrm{CD} 73^{-} \mathrm{CD} 25^{+} \mathrm{CD} 71^{+} \mathrm{Br} 1$ cells. Additionally, PLAspecific IgG4-switched memory B cells expanded after bee venom exposure [67]. The changes in the immune response induced upon venom immunotherapy have shown that 3-4 months after the start of the treatment, the frequency of PLA-specific IL10-producing Br1 cells increased two-fold to fivefold, reaching a level comparable to that of healthy beekeepers during the season [68-70]. Interestingly, PLA-specific B cells showed increased CCR5 expression after high-dose allergen exposure, whereas CXCR4, CXCR5, CCR6, and CCR7 expression remained unaffected $\left[{ }^{-"}\right]$. The prominent immunoregulatory profile of IL10-producing Breg cells characterized by upregulation of CD25 (IL-2 receptor a chain), programmed death-ligand 1 , suppressor of cytokine signaling 3 (SOCS3), and glycoprotein A repetitions predominant has been demonstrated by Stanic et al. [72"']. On a long-term follow-up of allergen-specific B cells during AIT in house dust mite allergy, we were able to show that $\mathrm{IgG}^{+}$and immunglobulin $\mathrm{A}(\operatorname{IgA})^{+}$Der $\mathrm{p}$ 1-specific B cells 
Table 1. The list of surface markers on Breg cells and $\mathrm{Br} 1$ cells

\begin{tabular}{|c|c|c|c|}
\hline Types & Human & Mouse & Function \\
\hline Breg cells $[60,83]$ & $\begin{array}{l}\mathrm{CD} 19^{+} \mathrm{CD} 5^{+} \mathrm{CD} 1 \mathrm{~d}^{+} \text {and } \\
\mathrm{CD} 19^{+} \mathrm{CD} 24^{+} \mathrm{CD} 38^{+}\end{array}$ & $\begin{array}{l}\mathrm{CD} 19^{+} \mathrm{CD} 1 \mathrm{~d}^{\text {hi }} \mathrm{CD}^{+} \\
\text {and } \mathrm{CD} 19^{+} \mathrm{CD}^{+}\end{array}$ & Suppress Th2 cells, and Th2 cytokines \\
\hline $\mathrm{Br} 1$ cells $[67,84]$ & $\mathrm{CD} 19^{+} \mathrm{CD} 73^{-} \mathrm{CD} 25^{+} \mathrm{CD} 71^{+}$ & $\mathrm{CD} 19^{+} \mathrm{CD}^{+}$ & $\begin{array}{l}\text { Suppress lgE production, upregulate } \\
\text { of lgG } 4 \text { production in human, and } \\
\text { increase IL- } 10 \text { production both } \\
\text { in human and mouse }\end{array}$ \\
\hline Immature B cells $[61,85-87]$ & $\mathrm{CD} 19^{+} \mathrm{CD} 24^{\mathrm{hi}} \mathrm{CD} 38^{\mathrm{hi}}$ & $\begin{array}{l}C D 19^{+} C D 21^{h i} C D 23^{h i} \\
C D 24^{h i} \lg M^{h i} \lg D^{h i} C D 1 d^{h i}\end{array}$ & $\begin{array}{l}\text { Transitional B cells based on the } \\
\text { phenotypes and ontogeny }\end{array}$ \\
\hline Plasmablasts [88] & $\mathrm{CD} 27^{\text {int }} \mathrm{CD} 38^{\mathrm{hi}}$ & $\mathrm{CD} 138^{+} \mathrm{CD} 44^{\mathrm{hi}}$ & $\begin{array}{l}\text { A short-lived and proliferating } \\
\text { antibody-secreting cells }\end{array}$ \\
\hline
\end{tabular}

Breg, regulatory B cells; Br1, allergen-specific Breg cells; Th2, T-helper 2 cells.

showed a significant increase after AIT. Responders showed a significantly greater frequency compared with nonresponders in the IgG4 but not the IgA fraction. The frequency of plasmablasts and IL- $10^{+}$ and/or IL-1RA ${ }^{+}$producing Breg cells was greater among responders compared with nonresponders after 2 years. The increased frequency of Der $\mathrm{p} 1$ specific IgG4 ${ }^{+}$B cells, plasmablasts, and $\mathrm{IL}-10^{+}$and dual-positive IL-10 ${ }^{+}$IL-1RA ${ }^{+}$Breg cells significantly correlated with improved clinical symptoms over the course of AIT. Therefore, allergen-specific B cells in patients responding to AIT are characterized by increased numbers of $\operatorname{IgA}^{+}$and $\operatorname{IgG} 4^{+}$expressing Der p 1-specific B cells, plasmablasts, and IL- $10^{+}$and/or IL-1RA ${ }^{+}$Breg cells [73"-']. In asthmatic mice, the adoptive transfer of $\mathrm{CD} 9(+) \mathrm{B}$ cells normalized airway inflammation and lung function by inhibiting Th2 and Th17-driven inflammation in an IL-10dependent manner, restoring a favorable immunological balance in lung tissues. They further showed that injection of $\mathrm{CD}^{+}$Breg cells controls the expansion of lung effector $\mathrm{T}$ cells allowing the establishment of a favorable regulatory $\mathrm{T}$ cells/effector $\mathrm{T}$ cells ratio in lungs [74]. Several surface markers on Breg cells are comprehensively described in a recent review article [64"']. Here, we provide a list of surface markers on different B-cell subsets in both human and mouse in Table 1.

Additionally, allergen-specific IgE which is produced by B cells indisputably plays a key role in determining the allergen specificity of allergic disease [75]. Characterization of B-cell receptor repertoires in different tissues and the evolution of $\operatorname{IgE}$ repertoires in allergen-specific B cells has become an interesting topic to enhance the understanding of allergic responses [76]. A recent study demonstrated that Ara h 2-specific circulating memory B cells are induced early and transiently in patients undergoing peanut oral immunotherapy and can be identified by using a fluorescent multimer. Immunoglobulins from these circulating Ara $\mathrm{h}$ 2-specific $\mathrm{B}$ cells are affinity matured and some clonal groups are shared among unrelated patients with peanut allergy [77]. Hoh et al. [78] showed peanut allergen-specific B cells in patients express mutated antibody genes, usually of switched isotypes and bind to both linear and conformational epitopes. Even well-defined linear epitopes of allergen proteins can be recognized by multiple independent B-cell clones in a single patient. Increased frequencies of allergen-binding B cells, progressive somatic mutation of IgG4, but not IgE, are observed during AIT [78]. Therefore, IgE repertoire persistence and evolution could be considered as markers for monitoring AIT in patients with allergic diseases [79].

Together these studies provide a first detailed characterization of allergen-specific B cells before and after immune tolerance induction in bee venom, house dust mite, and peanut allergies as shown in Table 2. It is clear that the responses of $B$ cells in AIT are very essential; however, to get a full understanding of all mechanisms, they need to be further investigated in-depth.

\section{CONCLUSION}

AIT has been considered as the most powerful treatment in patients who suffer from allergy, cancer, and autoimmune diseases $[13,80]$. Immune tolerance development was aimed for allergy and autoimmunity treatment, whereas enhancement of immune effector functions was aimed in cancer therapy. The development of immune tolerance requires allergen-specific Breg and Treg cells, increased IgG4 isotype-specific antibody response, and decreased activation of effector cells, such as basophils, mast cells, and eosinophils. Breg cells are interesting targets for the improvement of new therapies in the induction of immune tolerance. Advances in mechanisms of AIT has been aiming 
Table 2. B cells and antibody responses in the induction of allergen-specific immune tolerance

\begin{tabular}{|c|c|c|c|}
\hline Disease model & Types & Changes in the response to tolerant VS allergic state & References \\
\hline Bee venom allergy & Expansion of $\mathrm{Br} 1$ cells & $\begin{array}{l}\text { Increased frequencies of plasmablasts, PLA-specific memory B } \\
\text { cells, and IL-10-secreting CD73 }{ }^{-} \mathrm{CD} 25^{+} \mathrm{CD} 71^{+} \mathrm{Br} 1 \text { cells. PLA- } \\
\text { specific IgG4-switched memory B cells expanded after bee } \\
\text { venom exposure } \\
\text { Increased CCR5 expression after high-dose allergen exposure, } \\
\text { whereas CXCR4, CXCR5, CCR6, and CCR7 expression } \\
\text { remained unaffected }\end{array}$ & {$\left[67,71^{\square}\right]$} \\
\hline $\begin{array}{l}\text { House dust } \\
\text { mite allergy }\end{array}$ & Expansion of $\mathrm{Br} 1$ cells & $\begin{array}{l}\text { Increased numbers of IgA and lgG4-expressing Der } \mathrm{p} \text { 1-specific } \\
\text { B cells, plasmablasts, and IL-10 } 10^{+} \text {and/or IL-1RA }{ }^{+} \text {Breg cells }\end{array}$ & {$\left[73^{-"}\right]$} \\
\hline Peanut allergy & $\begin{array}{l}\text { Allergen-specific } \\
\text { antibodies }\end{array}$ & $\begin{array}{l}\text { Increasing somatic mutation of lgG4 B cells clones, whereas lgE } \\
\text { mutation levels in the clone did not increase } \\
\text { Ara h 2-specific B-cell receptor repertoire is oligoclonal and } \\
\text { somatically hypermutated and shares similar clonal groups in } \\
\text { AIT } \\
\text { The allergen-specific B cells clones had increased persistence, } \\
\text { higher likelihood of belonging to clones expressing other } \\
\text { switched isotypes, and possibly larger clone size }\end{array}$ & {$[77,78,79]$} \\
\hline
\end{tabular}

AIT, Allergen-specific immunotherapy; Breg, regulatory B cells; Brl, allergen-specific Breg cells; PLA, phospholipase A2.

to ensure that more efficient AIT vaccines are developed with low side-effects and higher efficacy and allergic patients will receive precise medical treatments $[81,82]$.

\section{Acknowledgements}

None.

\section{Financial support and sponsorship}

The authors' laboratories are supported by Swiss National Science Foundation (Grant No. 310030179428), Sean Parker Asthma and Allergy Center, Stanford University, USA.

\section{Conflicts of interest}

There are no conflicts of interest.

\section{REFERENCES AND RECOMMENDED \\ READING}

Papers of particular interest, published within the annual period of review, have been highlighted as:

- of special interest

- of outstanding interest

1. Agache I, Akdis CA. Precision medicine and phenotypes, endotypes, genotypes, regiotypes, and theratypes of allergic diseases. J Clin Invest 2019; 130:1493-1503.

2. Muraro $A$, Lemanske RF Jr, Castells $M$, et al. Precision medicine in allergic disease-food allergy, drug allergy, and anaphylaxis-PRACTALL document of the European Academy of Allergy and Clinical Immunology and the American Academy of Allergy, Asthma and Immunology. Allergy 2017; 72:1006-1021.

3. Pajno GB, Fernandez-Rivas M, Arasi S, et al. EAACl Guidelines on allergen immunotherapy: IgE-mediated food allergy. Allergy 2018; 73:799-815.

4. Roberts G, Pfaar O, Akdis CA, et al. EAACl guidelines on allergen immunotherapy: allergic rhinoconjunctivitis. Allergy 2018; 73:765-798.

5. Abuabara K, Yu AM, Okhovat JP, et al. The prevalence of atopic dermatitis beyond childhood: a systematic review and meta-analysis of longitudinal studies. Allergy 2018; 73:696-704.

6. Muraro A, Roberts G, Worm M, et al. Anaphylaxis: guidelines from the European Academy of Allergy and Clinical Immunology. Allergy 2014; 69:1026-1045.
7. Satitsuksanoa $P$, Jansen $K$, Globinska $A$, et al. Regulatory immune mechan-1. isms in tolerance to food allergy. Front Immunol 2018; 9:2939.

An excellent review on regulatory immune mechanisms that summarizes the induction of tolerance in food allergy.

8. Gonzalez-Delgado P, Caparros E, Moreno MV, et al. Clinical and immunological characteristics of a pediatric population with food protein-induced enterocolitis syndrome (FPIES) to fish. Pediatr Allergy Immunol 2016; 27:269-275.

9. Straumann A, Blanchard C, Radonjic-Hoesli S, et al. A new eosinophilic esophagitis (EoE)-like disease without tissue eosinophilia found in EoE families. Allergy 2016; 71:889-900.

10. Sherrill JD, Kc K, Wu D, et al. Desmoglein-1 regulates esophageal epithelial barrier function and immune responses in eosinophilic esophagitis. Mucosal Immunol 2014; 7:718-729.

11. Platts-Mills TA, Schuyler AJ, Erwin EA, et al. IgE in the diagnosis and treatment of allergic disease. J Allergy Clin Immunol 2016; 137:1662-1670.

12. Muraro $A$, Roberts $G$, Halken $S$, et al. EAACl guidelines on allergen immunotherapy: executive statement. Allergy 2018; 73:739-743.

13. Pfaar $\mathrm{O}$, Bonini $\mathrm{S}$, Cardona $\mathrm{V}$, et al. Perspectives in allergen immunotherapy: 2017 and beyond. Allergy 2018; 73(Suppl 104):5-23.

14. Mueller RS, Jensen-Jarolim E, Roth-Walter F, et al. Allergen immunotherapy in people, dogs, cats and horses-differences, similarities and research needs. Allergy 2018; 73:1989-1999.

15. Globinska A, Boonpiyathad T, Satitsuksanoa $P$, et al. Mechanisms of allergen-

- specific immunotherapy: diverse mechanisms of immune tolerance to allergens. Ann Allergy Asthma Immunol 2018; 121:306-312.

A comprehensive review on mechanisms of allergen-specific immunotherapy.

16. Arzt $L$, Bokanovic $D$, Schrautzer $C$, et al. Immunological differences between insect venom-allergic patients with and without immunotherapy and asymptomatically sensitized subjects. Allergy 2018; 73:1223-1231.

17. Reitsma S, Subramaniam S, Fokkens WW, Wang Y. Recent developments and highlights in rhinitis and allergen immunotherapy. Allergy 2018; 73:2306-2313.

18. Sturm GJ, Varga EM, Roberts G, et al. EAACl guidelines on allergen immunotherapy: Hymenoptera venom allergy. Allergy 2018; 73:744-764.

19. van de Veen W, Wirz OF, Globinska A, Akdis M. Novel mechanisms in immune tolerance to allergens during natural allergen exposure and allergen-specific immunotherapy. Curr Opin Immunol 2017; 48:74-81.

20. Agache I. EAACl guidelines on allergen immunotherapy: out with the old and in with the new. Allergy 2018; 73:737-738.

21. Devillier $P$, Molimard $M$, Ansolabehere $X$, et al. Immunotherapy with grass pollen tablets reduces medication dispensing for allergic rhinitis and asthma: a retrospective database study in France. Allergy 2018; 74:1317-1326.

22. Hesse $L$, van leperen $N$, Habraken $C$, et al. Subcutaneous immunotherapy with purified Der $\mathrm{p} 1$ and 2 suppresses type 2 immunity in a murine asthma model. Allergy 2018; 73:862-874.

23. Rondon C, Blanca-Lopez $N$, Campo $P$, et al. Specific immunotherapy in local allergic rhinitis: a randomized, double-blind placebo-controlled trial with Phleum pratense subcutaneous allergen immunotherapy. Allergy 2018; 73:905-915.

24. Pfaar O. Sublingual immunotherapy with house dust mite tablets in children: the evidence-based journey of allergen immunotherapy proceeds. Allergy 2018; 73:2271-2273. 
25. Ihara $F$, Sakurai $D$, Yonekura S, et al. Identification of specifically reduced Th2 cell subsets in allergic rhinitis patients after sublingual immunotherapy. Allergy 2018; 73:1823-1832

26. Zielen $S$, Devillier $P$, Heinrich J, et al. Sublingual immunotherapy provides long-term relief in allergic rhinitis and reduces the risk of asthma: a retrospective, real-world database analysis. Allergy 2018; 73:165-177.

27. Masuyama K, Okamoto $\mathrm{Y}$, Okamiya $\mathrm{K}$, et al. Efficacy and safety of $\mathrm{SQ}$ house dust mite sublingual immunotherapy-tablet in Japanese children. Allergy 2018; 73:2352-2363.

28. Akdis M, Akdis CA. Mechanisms of allergen-specific immunotherapy: multiple suppressor factors at work in immune tolerance to allergens. J Allergy Clin Immunol 2014; 133:621-631.

29. Akdis CA, Akdis M. Mechanisms of allergen-specific immunotherapy and immune tolerance to allergens. World Allergy Organ J 2015; 8:17.

30. Palomares $\mathrm{O}$, Akdis M, Martin-Fontecha M, Akdis CA. Mechanisms of immune regulation in allergic diseases: the role of regulatory $\mathrm{T}$ and $\mathrm{B}$ cells. Immunol Rev 2017; 278:219-236.

31. Pali-Scholl I, De Lucia M, Jackson $H$, et al. Comparing immediate-type food allergy in humans and companion animals: revealing unmet needs. Allergy 2017; 72:1643-1656

32. Soares MP, Teixeira L, Moita LF. Disease tolerance and immunity in host protection against infection. Nat Rev Immunol 2017; 17:83-96.

33. Akdis M, Aab A, Altunbulakli C, et al. Interleukins (from IL-1 to IL-38), interferons, transforming growth factor beta, and TNF-alpha: receptors, functions, and roles in diseases. J Allergy Clin Immunol 2016; 138:984-1010.

34. Akdis CA, Akdis M. Mechanisms of immune tolerance to allergens: role of IL10 and Tregs. J Clin Invest 2014; 124:4678-4680.

35. Arango Duque G, Descoteaux A. Macrophage cytokines: involvement in immunity and infectious diseases. Front Immunol 2014; 5:491.

36. Jutel $M$, Akdis $M$, Blaser $K$, Akdis CA. Mechanisms of allergen specific immunotherapy: T-cell tolerance and more. Allergy 2006; 61:796-807.

37. Akdis CA. Therapies for allergic inflammation: refining strategies to induce tolerance. Nat Med 2012; 18:736-749.

38. Morita $\mathrm{H}$, Kubo $\mathrm{T}$, Ruckert $\mathrm{B}$, et al. Induction of human regulatory innate lymphoid cells from group 2 innate lymphoid cells by retinoic acid. J Allergy Clin Immunol 2019; 143:2190-2201.

39. Sugita K, Steer CA, Martinez-Gonzalez I, et al. Type 2 innate lymphoid cells disrupt bronchial epithelial barrier integrity by targeting tight junctions through IL-13 in asthmatic patients. J Allergy Clin Immunol 2018; 141:300.e11-310.e11.

40. Sokolowska M, Akdis CA. Highlights in immune response, microbiome and precision medicine in allergic disease and asthma. Curr Opin Immunol 2017; 48:iv-ix.

41. Liedtke JP, Mandl A, Kother J, et al. RCAT reflects symptom control and quality of life in allergic rhinoconjunctivitis patients. Allergy 2018; 73:1101-1109.

42. Fujita $H$, Soyka MB, Akdis $M$, Akdis $C A$. Mechanisms of allergen-specific immunotherapy. Clin Transl Allergy 2012; 2:2.

43. Jutel $M$, Akdis $C A$. Immunological mechanisms of allergen-specific immunotherapy. Allergy $2011 ; 66: 725-732$.

44. Soyka MB, Holzmann D, Akdis CA. Regulatory cells in allergen-specific immunotherapy. Immunotherapy 2012; 4:389-396.

45. Komlósi Zl, Kovacs N, van de Veen W, et al. Human CD40 ligand-expressing

- type 3 innate lymphoid cells induce IL-10-producing immature transitional regulatory B cells. J Allergy Clin Immunol 2018; 142:178.e11-194.e11.

This study demonstrated that human CD40 ligand-expressing type 3 innate

lymphoid cells are able to induce IL-10-producing immature transitional regulatory $\mathrm{B}$ cells.

46. Akdis CA, Blesken $T$, Akdis $M$, et al. Role of interleukin 10 in specific immunotherapy. J Clin Invest 1998; 102:98-106.

47. Shin JU, Kim SH, Noh JY, et al. Allergen-specific immunotherapy induces

- regulatory $T$ cells in an atopic dermatitis mouse model. Allergy 2018; 73:1801-1811.

This study indicated AIT induces the expansion of Treg cells in mouse model with atopic dermatitis.

48. Ozdemir C, Kucuksezer UC, Akdis M, Akdis CA. Mechanisms of immunotherapy to wasp and bee venom. Clin Exp Allergy 2011; 41:1226-1234.

49. Meiler F, Zumkehr J, Klunker S, et al. In vivo switch to IL-10-secreting T regulatory cells in high dose allergen exposure. J Exp Med 2008; 205:2887-2898.

50. Senti G, Crameri R, Kuster D, et al. Intralymphatic immunotherapy for cat allergy induces tolerance after only 3 injections. J Allergy Clin Immunol 2012; 129:1290-1296.

51. Davila I, Dominguez-Ortega J, Navarro-Pulido A, et al. Consensus document on dog and cat allergy. Allergy 2018; 73:1206-1222.

52. Akdis $C A$, Barlan IB, Bahceciler $N$, Akdis M. Immunological mechanisms of sublingual immunotherapy. Allergy 2006; 61(Suppl 81):11-14.

53. Ciprandi G, Fenoglio D, Cirillo I, et al. Sublingual immunotherapy and regulatory T cells. Allergy 2006; 61:511-513.

54. Boonpiyathad $T$, Sokolowska $M$, Morita $H$, et al. Der $p$ 1-specific regulatory $T$ -

I. cell response during house dust mite allergen immunotherapy. Allergy 2019; $74: 976-985$.

This study emphasized the important responses of allergen-specific T-cell during house dust mite AIT.
55. Baecher-Allan C, Viglietta V, Hafler DA. Human CD4+CD25+ regulatory $T$ cells. Semin Immunol 2004; 16:89-98.

56. Ito $\mathrm{T}$, Hanabuchi $\mathrm{S}$, Wang $\mathrm{YH}$, et al. Two functional subsets of FOXP3+ regulatory $T$ cells in human thymus and periphery. Immunity 2008; 28:870-880.

57. Joss $A$, Akdis M, Faith $A$, et al. IL-10 directly acts on $T$ cells by specifically altering the CD28 co-stimulation pathway. Eur J Immunol 2000; 30:1683-1690.

58. Kearley J, Barker JE, Robinson DS, Lloyd CM. Resolution of airway inflammation and hyperreactivity after in vivo transfer of CD4+CD25+ regulatory $\mathrm{T}$ cells is interleukin 10 dependent. J Exp Med 2005; 202:1539-1547.

59. Smaldini PL, Trejo F, Cohen JL, et al. Systemic IL-2/anti-IL-2Ab complex combined with sublingual immunotherapy suppresses experimental food allergy in mice through induction of mucosal regulatory $T$ cells. Allergy 2018; 73:885-895

60. Yanaba K, Bouaziz JD, Haas KM, et al. A regulatory $\mathrm{B}$ cell subset with a unique CD1dhiCD5+ phenotype controls T cell-dependent inflammatory responses. Immunity 2008; 28:639-650.

61. Blair PA, Norena LY, Flores-Borja F, et al. CD19(+)CD24(hi)CD38(hi) B cells exhibit regulatory capacity in healthy individuals but are functionally impaired in systemic lupus erythematosus patients. Immunity 2010; 32:129-140.

62. Wirz OF, Globinska A, Ochsner U, et al. Comparison of regulatory $B$ cells in

n. asthma and allergic rhinitis. Allergy 2019; 74:815-818.

This study compared the responses of Breg cells in patients with asthma and allergic rhinitis.

63. van de Veen $\mathrm{W}$. The role of regulatory $\mathrm{B}$ cells in allergen immunotherapy. Curr

- Opin Allergy Clin Immunol 2017; 17:447-452.

An excellent review which summarizes the role of Breg cells during AIT in both cellular and molecular aspects.

64. van de Veen W, Stanic B, Wirz OF, et al. Role of regulatory B cells in immune

n- tolerance to allergens and beyond. J Allergy Clin Immunol 2016; 138:654-665.

This intensive review describes important roles of Breg cells in tolerance to allergens.

65. van de Veen W, Akdis M. Role of lgG4 in lgE-mediated allergic responses. J

- Allergy Clin Immunol 2016; 138:1434-1435.

lgG4 responses in IgE-mediated allergic diseases were clearly described in this review.

66. Braza $\mathrm{F}$, Chesne J, Castagnet $\mathrm{S}$, et al. Regulatory functions of $\mathrm{B}$ cells in allergic diseases. Allergy 2014; 69:1454-1463.

67. van de Veen W, Stanic B, Yaman G, et al. IgG4 production is confined to human IL-10-producing regulatory $B$ cells that suppress antigen-specific immune responses. J Allergy Clin Immunol 2013; 131:1204-1212.

68. Sokolowska M, Stefanska J, Wodz-Naskiewicz K, et al. Cytosolic phospholipase A2 group IVA is overexpressed in patients with persistent asthma and regulated by the promoter microsatellites. J Allergy Clin Immunol 2010; 125:1393-1395.

69. Sokolowska M, Borowiec M, Ptasinska A, et al. 85-kDa cytosolic phospholipase A2 group IValpha gene promoter polymorphisms in patients with severe asthma: a gene expression and case-control study. Clin Exp Immunol 2007; 150:124-131.

70. Pniewska E, Sokolowska M, Kuprys-Lipinska I, et al. The step further to understand the role of cytosolic phospholipase A2 alpha and group $X$ secretory phospholipase A2 in allergic inflammation: pilot study. Biomed Res Int 2014; 2014:670814.

71. Boonpiyathad T, Meyer N, Moniuszko M, et al. High-dose bee venom exposure

I. induces similar tolerogenic B-cell responses in allergic patients and healthy beekeepers. Allergy 2017; 72:407-415.

This study firstly demonstrated tolerogenic B-cell responses in allergic patients and healthy beekeepers.

72. Stanic $B$, van de Veen $W$, Wirz OF, et al. IL-10-overexpressing $B$ cells regulate

- innate and adaptive immune responses. J Allergy Clin Immunol 2015; 135:771.e8-780.e8.

This study highlighted an essential role for IL-10 in inducing an immunoregulatory phenotype in B cells that exerts substantial antiinflammatory and immunosuppressive functions.

73. Boonpiyathad $T$, van de Veen W, Wirz O, et al. Role of Der $\mathrm{p} 1$-specific B cells

n. in immune tolerance during 2 years of house dust mite-specific immunotherapy. J Allergy Clin Immunol 2019; 143:1077.e10-1086.e10.

This study clearly demonstrated the role of allergen-specific B cells in HDM-AIT with an increased number of $\lg A$ and $\lg G 4$-expressing Der $p$ 1-specific B cells, plasmablasts, and IL- $10^{+}$and/or IL-1RA ${ }^{+}$Breg cells.

74. Braza F, Chesne J, Durand $M$, et al. A regulatory CD9(+) B-cell subset inhibits HDM-induced allergic airway inflammation. Allergy 2015; 70:1421-1431.

75. Gadermaier $E$, Levin $M$, Flicker S, Ohlin M. The human IgE repertoire. Int Arch Allergy Immunol 2014; 163:77-91.

76. Kerzel S, Rogosch T, Struecker B, et al. IgE transcripts in the circulation of allergic children reflect a classical antigen-driven $B$ cell response and not a superantigen-like activation. J Immunol 2010; 185:2253-2260.

77. Patil SU, Ogunniyi AO, Calatroni $A$, et al. Peanut oral immunotherapy transiently expands circulating Ara $\mathrm{h}$ 2-specific B cells with a homologous repertoire in unrelated subjects. J Allergy Clin Immunol 2015; 136:125.e12-134.e12. 
78. Hoh RA, Joshi SA, Liu Y, et al. Single B-cell deconvolution of peanut-specific antibody responses in allergic patients. J Allergy Clin Immunol 2016; 137:157-167.

79. Levin M, King JJ, Glanville J, et al. Persistence and evolution of allergenspecific $\lg$ E repertoires during subcutaneous specific immunotherapy. J Allergy Clin Immunol 2016; 137:1535-1544.

80. Jensen-Jarolim E, Bax HJ, Bianchini R, et al. AllergoOncology: opposite outcomes of immune tolerance in allergy and cancer. Allergy 2018; 73:328-340.

81. Asaria $M$, Dhami $S$, van Ree $R$, et al. Health economic analysis of allergen immunotherapy for the management of allergic rhinitis, asthma, food allergy and venom allergy: a systematic overview. Allergy 2018; 73: 269-283.

82. Bonertz A, Roberts G, Slater JE, et al. Allergen manufacturing and quality aspects for allergen immunotherapy in Europe and the United States: an analysis from the EAACl AIT Guidelines Project. Allergy 2018; $73: 816-826$.
83. Iwata $\mathrm{Y}$, Matsushita $\mathrm{T}$, Horikawa $\mathrm{M}$, et al. Characterization of a rare IL-10competent $\mathrm{B}$-cell subset in humans that parallels mouse regulatory $\mathrm{B} 10$ cells. Blood 2011; 117:530-541.

84. O'Garra A, Chang R, Go N, et al. Ly-1 B (B-1) cells are the main source of $B$ cell-derived interleukin 10. Eur J Immunol 1992; 22:711-717.

85. Menon M, Blair PA, Isenberg DA, Mauri C. A regulatory feedback between plasmacytoid dendritic cells and regulatory $B$ cells is aberrant in systemic lupus erythematosus. Immunity 2016; 44:683-697.

86. Bosma A, Abdel-Gadir A, Isenberg DA, et al. Lipid-antigen presentation by $\mathrm{CD} 1 \mathrm{~d}(+) \mathrm{B}$ cells is essential for the maintenance of invariant natural killer $\mathrm{T}$ cells. Immunity 2012; 36:477-490.

87. Evans JG, Chavez-Rueda KA, Eddaoudi A, et al. Novel suppressive function of transitional 2 B cells in experimental arthritis. J Immunol 2007; 178:7868-7878.

88. Matsumoto M, Baba A, Yokota T, et al. Interleukin-10-producing plasmablasts exert regulatory function in autoimmune inflammation. Immunity 2014; 41:1040-1051. 